\title{
Pelatihan Penggunaan Media ICT Online bagi Guru, Orang Tua dan Siswa SMP IT Insan Mulia Manokwari berupa Edmodo dan Schoology
}

\author{
Achmad Rante Suparman ${ }^{1}$ \\ Universitas Papua, achmad.unipa@gmail.com \\ Fridolin F Paiki² \\ Universitas Papua, f.paiki@unipa.ac.id
}

\begin{abstract}
Abstrak
Tujuan utama pengabdian masyarakat berupa pelatihan penggunaan media ICT online bagi guru, orang tua dan siswa di SMP IT Insan Mulia Manokwari adalah mengenalkan jenis-jenis media online yang yang dapat digunakan dalam proses pembelajaran berupa Edmodo dan Schoology. Pelatihan dilakukan dengan terperinci, dengan membagi kelas guru, kelas orang tua dan kelas siswa dalam mempelajari penggunaan media ICT berupa Edmodo dan Schoology. Dalam proses pelatihan dilakukan pendampingan yang dilakukan oleh tim PKM. Disamping pengenalan media ICT, dalam pelatihan ini dilakukan juga penugasan agar lebih memahami tentang penggunaan media ICT online tersebut. Penugasan dibedakan antara tugas guru, tugas orang tua dan tugas siswa. Untuk mengetahui keberhasilan kegiatan pengabdian ini, dilakukan evaluasi tahap akhir. Evaluasi dilakukan dengan dua cara yaitu wawancara dan pengisian angket. Hasil evaluasi tersebut di olah dan dibuat dalam bentuk diagram pelaksanaan kegiatan. Hasil evaluasi dari kegiatan ini disampaikan kepada pihak sekolah dan pihak-pihak terkait. Dari hasil tersebut diperoleh bahwa tingkat kepuasan peserta pelatihan sangat tinggi, dimana $92 \%$ puas dengan proses pelatihan, baik dari segi materi, penyampaian materi, proses diskusi, pelatihan individu dan hasil penelitian. Pengabdian ini menambah pengetahuan dan keterampilan peserta pelatihan
\end{abstract}

Kata Kunci: ICT, Edmodo, Schoology

\begin{abstract}
The main purpose of community service in the form of training in the use of online ICT media for teachers, parents, and students at SMP IT Insan Mulia Manokwari are to introduce the types of online media that can be used in the learning process in the form of Edmodo and Schoology. The training was conducted in detail, by dividing the teacher class, the class of parents and students in learning the use of ICT media in the form of Edmodo and Schoology. In the training, process assistance was carried out by the PKM team. In addition to the introduction of ICT media, assignments were also carried out to understand more about the use of online ICT media. Assignments are distinguished between teacher assignments, parental duties, and student assignments. To find out the success of this service activity, the final evaluation was carried out. The evaluation was conducted in two ways, namely interview and questionnaire filling. The results of the evaluation are processed and made in the form of an activity implementation diagram. The results of the evaluation of this activity were submitted to the school and related parties. From these results, it was found that the
\end{abstract}


level of satisfaction of the trainees was very high of which $92 \%$ were satisfied with the training process, both in terms of material, delivery of material, discussion processes, individual training, and research results. This service adds to the training participants' knowledge and skills

Keywords: ICT, Edmodo, Schoology

\section{Pendahuluan}

Perkembangan teknologi sekarang terjadi dengan pesat, baik teknologi informasi maupun teknologi komunikasi, menuntut pengajar untuk mampu menggunakan media pembeajaran yang tepat bagi siswanya. Penggunaan media yang tepat merupakan suatu alternatif untuk mengatasi rendahnya hasil belajar siswa khususnya pada siswa di Papua Barat. Menurut (Nursidik, 2007), kata media berasal dari bahasa latin Medius yang secara harafiah berarti tengah, perantara, atau pengantar, namun pengertian media dalam proses pembelajaran cenderung diartikan sebagai alat-alat grafis, fotografis atau elektronis untuk menagkap, memproses, dan menyusun kembali informasi visual atau verbal. Sedangkan (McLuhan, 2002) berpendapat bahwa media adalah suatu ekstensi manusia yang memungkinkannya mempengaruhi orang lain yang tidak mengadakan kontak langsung dengan dia. Penggunaan media pembelajaran yang tepat dalam mengajar, diharapkan mampu meningkatkan hasil belajar siswa. Pemilihan media harus mempertimbangkan sisi kecocokan materi yang diajarkan serta keadaan siswa yang meliputi kemampuan maupun waktu yang dimiliki.

(Kamil, 2004) mengemukakan bahwa peranan media pembelajaran sangatlah penting dalam proses transformasi ilmu pengetahuan itu sendiri, karena media pembelajaran ini sangat penting untuk diperadakan dimana media pelajaran diperuntukkan untuk memotivasi siswa, memberikan pengalaman serta mempermudah siswa dalam mencerna dan menganalisis konsep-konsep kimia yang abstrak.

Seiring dengan kemajuan teknologi sekarang ini, HP android dapat dimanfaatkan sebagai salah satu komponen dalam media pembelajaran yang efektif dan efisien dalam bentuk hardware. Komponen lain berupa aplikasi dapat dipadukan dengan memanfaatkan HP android menciptakan suatu media pembelajaran Teknologi Informasi berbasis online. Apalagi hampir setiap siswa dan guru mempunyai HP android ini yang jumlahnya cukup memadai untuk digunakan dalam proses pembelajaran serta siswa mempunyai keterampilan memadai juga untuk menggunakan HP jenis android.

Sebagai sebuah produk, media teknologi informasi merupakan hasil pemecahan suatu masalah berdasarkan pendekatan komunikasi visual. Dalam era modern seperti sekarang, dimana media sosial lebih mendominasi dalam kehidupan seharihari, guru dituntut untuk mampu mengikuti perkembangan teknologi yang ada. Ada berbagai media yang dapat digunakan dalam proses pembelajaran, salah satunya adalah Edmodo dan Schoology. Media ini dapat diterapakan pada siswa karena hampir seluruh siswa sekarang menggunakan HP jenis android. Aplikasi Edmodo dan Schoology dapat didownload terdapat pada play store. Tampilan dan penggunaan Edmodo dan Schoology yang menyerupai tampilan Facebook mampu 


\section{JURNAL ABDIMAS BSI}

Jurnal Pengabdian Kepada Masyarakat

menarik daya minat siswa dalam menggunakannya, sehingga dapat berdampak pada hasil belajar yang diperoleh.

Menurut (Kuntarto, 2018) edmodo adalah salah satu platform media sosial yang sering digunakan dalam ELearning. Edmodo digambarkan sebagai Facebook untuk Institusi Pendidikan dan

Dapat berfungsi lebih banyak lagi sesuai dengan kebutuhan. Edmodo merupakan aplikasi yang menarik bagi Dosen dan Mahasiswa dengan elemen sosial yang menyerupai Facebook, tapi sesungguhnya ada nilai lebih besar dalam aplikasi edukasi berbasis jejaring sosial ini. Edmodo (dirancang oleh Dosen) yang juga berbasis cloud kolaborasi merupakan aplikasi yang cukup aman digunakan oleh Dosen dan Mahasiswa . Seorang Dosen dan Institusi Pendidikan (Perguruan Tinggi) dapat dengan mudah mengelola sebuah sistem yang menyediakan fitur terbaik dan praktis bagi pendidikan daring yang dilakukan dengan memanfaatkan internet. Dengan platform ini akan lebih mudah untuk memonitor interaksi Mahasiswa dalam Edmodo learning environment. Tidak ada yang bisa masuk ke ruang Edmodo tanpa undangan, dan mahasiswa tidak dapat menggunakannya untuk berhubungan dengan orang asing seperti yang terjadi di facebook, sehingga dapat dengan mudah mengetahui jika ada pelanggar/penyusup/ orang asing yang terdaftar di kelas yang dikelola dengan Edmodo.

Hasil penelitian (Hikmawan \& Sarino, 2018) menyimpulkan bahwa pemanfaatan media pembelajaran berbasis edmodo pada Sekolah Menengah Kejuruan (SMK) Swasta di Kota Cimahi berada pada kategori cukup kuat dalam mempengaruhi motivasi belajar siswa. Dalam pengaruhnya pemanfaatan media pembelajaran memiliki pengaruh positif yang cukup kuat dan signifikan terhadap motivasi belajar siswa. Hal ini menunjukan bahwa motivasi belajar siswa dapat dipengaruhi oleh media pembelajaran berbasis edmodo. Meskipun pengaruh yang dihasilkan oleh variabel media pembelajaran berbasis edmodo kuat, tetapi variabel ini sangat signifikan dan memilik pengaruh yang timbal balik dalam memberikan pengaruh terhadap motivasi belajar siswa.

Selain aplikasi edmodo, aplikasi lain yang dapat digunakan adalah Schoology. Kelebihan Schoology adalah tersedianya fasilitas Attandance/absensi, yang digunakan untuk mengecek kehadiran peserta didik, dan juga fasilitas Analityc untuk melihat semua aktivitas peserta didik pada setiap course, assignment, discussion dan aktivitas lain yang kita siapkan untuk peserta didik. Melalui fitur analytic ini, kita juga bisa melihat di mana saja atau pada aktivitas apa saja seorang peserta didik biasa menghabiskan waktu mereka ketika dia login.

Hasil Penelitian (Ulva, Kantun, \& Widodo, 2017) menyimpulkan bahwa Berdasarkan hasil penelitian dan pembahasan, dapat disimpulkan bahwa penerapan E-Learning dengan media Schoology dapat meningkatkan motivasi dan hasil belajar siswa pada kompetensi dasar mendeskripsikan konsep badan usaha dalam perekonomian Indonesia kelas X SOS 1 SMAN 4 Jember tahun ajaran 2016/2017.

Penggunaan media e learning berupa edmodo dan schoology mewajibkan peserta didik akan selalu terhubung dengan jaringan internet. Pengawasan yang positif dari guru serta orang tua sangat digarpakan agar peserta didik tidak mengakses hal-hal yang sifatnya negatif. Hal ini sejalan dengan hasil pengabdian (Apriyani, Sutisna, \& 


\section{JURNAL ABDIMAS BSI}

Jurnal Pengabdian Kepada Masyarakat

Adiwisasta, 2018) yang memberikan kesimpulan bahwa pendampingan dan pengawasan orang tua ataupun guru dalam pemanfaatan media social serta kuatnya pondasi ilmu dan agama yang dimiliki seorang remaja dapat menjadi benteng dari pengaruh negatif yang didapatkan, selain itu dapat memberikan pengaruh posistif kepada siswa/santri untuk dapat memanfaatkan media social sebagai tempat untuk mengembangkan bakat yang ada ataupun dapat digunakan sebagai alat berwirausaha.

SMP Islam Terpadu Insan Mulia adalah salah satu sekolah yang berada di kota manokwari Provinsi Papua Barat yang telah menerapkan Full Day School bagi siswasiswanya. Untuk mengisi waktu luang siswa terkadang diberi tugas sekolah agar mampu dikerjakan dengan teman-temannya.

Tugas merupakan hal wajib yang harus diberikan kepada siswa untuk memancing mereka agar dapat belajar dirumah mereka masing-masing. Tugas biasa yang digunakan dengan menggunakan kertas, akan membuat siswa jenuh dan lebih cenderung untuk bermain sosial media yang tampilannya lebih menarik. Selain itu, siswa berpendapat bahwa orang tua mereka tidak mengetahui ketika ada tugas dari guru, sehingga mereka merasa tidak dikontrol oleh orang tua dan berdampak pada rasa malas dalam mengerjakan tugas atau pembelajaran yang diberikan oleh guru.

Permasalahan yang kadang terjadi adalah siswa terkadang tidak mengerjakan tugas dan bahkan malas masuk sekolah. Orang tua siswa kadang memprotes sekolah dengan alasan bahwa anak mereka selalu rajin ke sekolah dan selalu rutin mengerjakan tugas, padahal pada kenyataannya adalah bahwa anak mereka jarang sampai ke sekolah dan tugasnya pun hampir tidak ada.

Dengan pertimbangan tersebut, maka solusi yang dapat digunakan agar siswa dapat tetap bermain dengan rutinitas yang sifatnya online akan tetapi juga ikut mengerjakan tugas yang diberikan oleh guru, maka media pembelajaran ICT online berupa Edmodo dan Schoology merupakan suatu solusi yang tepat. Tampilannya yang hampir sama dengan facebook dapat membuat siswa betah dan serius dalam mengerjakan tugas yang diberikan secara online dalam aplikasi tersebut.

Selain itu, dengan menggunakan aplikasi Edmodo dan Schoology orang tua mempunyai peranan yang lebih dari biasanya karena dengan aplikasi ini, orang tua siswa juga memiliki akun sehingga dapat mengontrol setiap aktifitas anaknya, baik dalam mengerjakan tugas maupun kuis yang diberikan oleh guru. Aplikasi ini mirip aplikasi twitter, dimana oarng tua bisa follow akun anaknya, sehingga kontrol tehadap anaknya dalam aktivitas belajar lebih maksimal. Kontrol yang dilakukan guru dan orang tua siswa ini dapat dilakukan dimana pun karena sistemnya yang online dan aplikasi ada pada play store yang dapat dengan mudah di download. Dengan adanya aplikasi Edmodo dan Schoology ini, peranan orang tua lebih terasa dan dapat memantau perkembangan anak-anak mereka selama disekolah, baik dari segi kehadiran maupun dari segi pengerjaan tugas yang diberikan oleh guru, sehingga diharapkan tidak ada lagi orang tua siswa yang datang ke sekolah hanya untuk mengamuk sambil membawa senjata tajam atau marah-marah karena anaknya mendapat nilai yang jelek atau karena tinggal kelas.

Untuk memaksimalkan penggunaan media ICT online yang berupa Edmodo dan Schoology tersebut, maka guru, orang tua dan siswa perlu mengetahui dan 
memahami cara penggunaan media ICT tersebut. Guru perlu memahami cara memasukkan bahan ajar, gambar, tugas, kuis serta cara menilai kerja siswa berdasarkan media online yang digunakan. Orang tua perlu memahami bagaimana cara mengontrol anak meraka dalam proses pembelajaran dan siswa perlu memahami cara mengerjakan tugas, kuis serta cara download bahan ajar yang diberikan oleh guru pada aplikasi Edmodo dan Schoology.

\section{Metode}

Metode pelaksanaan yang dilaksanakan dalam Pelatihan Penggunaan Media ICT Online Bagi Guru, Orang Tua dan Siswa SMP IT Insan Mulia Manokwari Berupa Edmodo Dan Schoology adalah dengan pelatihan secara berkelanjutan. Tahapan pertama yang dilakukan adalah dengan mendata jumlah guru, siswa dan orang tua yang berada di SMP IT Insan Mulia Manokwari.

Langkah selanjutnya adalah dengan melakukan analisis tentang tingkat kemahiran penggunaan media ICT berupa komputer dan HP android bagi guru, siswa dan orang tua siswa. Setelah mengetahui tingkat kemampuan siswa, guru dan orang tua maka memberikan pelatihan singkat awal kepada orang tua, siswa dan guru tentang penggunaan komputer dan HP adroid dengan tujuan agar pada saat pelatihan media ICT Edmodo dan Schoology tidak mengalami kesulitan.

Langkah selanjutnya adalah dengan membagi kelas besar menjadi tiga yaitu kelas Guru, kelas siswa dan kelas orang tua. Pelatihan pertama yang dilakukan adalah dengan pelatihan penggunaan media ICT Edmodo dan Schoology bagi guru. Pelatihan ini akan dilatih oleh dua orang Tim pengusul PKM dan dibantu oleh tenaga administrasi dan teknisi. Selanjutnya memberikan tugas mandiri kepada guru dengan tujuan agar lebih memahami aplikasi media ICT Edmodo dan Schoology.

Pelatihan kedua yang dilakukan adalah dengan melakukan pelatihan kepada siswa cara menggunakan media ICT Edmodo dan Schoology, baik dari cara mengerjakan tugas, absensi dan sebaginya.

Pelatihan ketiga yang dilakukan adalah dengan pelatihan kepada orang tua siswa cara menggunakan media ICT Edmodo dan Schoology dan mengontrol kemakhiran orangtua dalam menggunakan media ICT Edmodo dan Schoology.

Dalam pelatihan yang dilaksanakan, baik di kelas guru, siswa dan orang tua, pihak sekolah dalam hal ini adalah mitra akan selalu bersifat kooperatif dalam penyedian ruang untuk pelatihan dan fasilitas wifi sekolah. Setelah selesai semua pelatihan Tim PKM tetap berkoordinasi dengan Tim mitra sekolah untuk memantau penggunaan media ICT Edmodo dan Schoology. Untuk mengetahui tingkat kepuasan dan keberlanjutan program ini dilakukan evaluasi. Evaluasi yang dilakukan adalah menggunakan angket kepuasan yang akan di isi oleh guru, siswa dan orang tua. Hasil dari evaluasi ini akan dipresentasikan di depan guru, siswa dan orang tua.

\section{Hasil dan Pembahasan}

Pada kegiatan pengabdian masyarakat ini, diimplementasikan penggunaan media ICT dalam pembelajaran dengan memanfaatkan aplikasi Edmodo dan Schoology. Tim mitra adalah SMP IT Insan Mulia Manokwari yang melibatkan guru, orang tua dan siswa SMP IT Insan Mulia Manokwari. 
Tim pengabdian memulai kegiatan dengan menghubungi kepala sekolah sebagai pimpinan tertinggi yang berada di lingkup sekolah SMP IT Insan Mulia Manokwari. Kepala Sekolah menyambut dengan baik kegiatan yang dilaksanakan di sekolahnya ini dan akan mengusahakan agar semua guru terlibat dalam kegiatan pengabdian ini.

Tim pengabdian terdiri atas 2 dosen dengan bidang ilmu yang berbeda, yaitu bidang Pendidikan dan bidang computer atau informasi, serta melibatkan 3 orang mahasiswa. Pertemuan atau rapat koordinasi pertama yang dilakukan oleh tim mendapat kesepakatan tentang jadwal dan rangkaian kegiatan pengabdian yang akan dilaksanakan.

Langkah pertama yang dilakukan oleh tim pengabdian adalah dengan mengunjungi lokasi tim mitra, berbicara langsung dengan kepala sekolah tentang rangkaian jadwal yang akan dilaksanakan selama proses kegiatan pengabdian berlangsung. Hal ini disambut positif oleh kepala sekolah SMP IT Insan Mulia Manokwari.

Langkah selanjutnya yang dilakukan oleh tim adalah dengan mendata kemampuan guru yang ada di sekolah tentang penggunaan computer dan penggunaan HP. Pendataan ini dilakukan dengan cara pendekatan kekeluargaan dan dilakukan dengan cara mengobrol secara santai, jadi tidak terjadi penekanan pertanyaan. Pendataan ini dilakukan secara beberapa hari secara langsung ke sekolah maupun lewat komunikasi menggunakan HP. Kegiatan pendataan kemampuan ini tidak disadari oleh responden sehingga diharapkan datanya akurat.

Setelah mendapatkan data dan informasi, selanjutnya tim pengbadian melakukan rapat lanjutan untuk menyusun bentuk pengabdian masyarakat yang akan dilaksanakan di SMP IT Insan Mulia Manokwari. Dari hasil rapat diputuskan untuk melaksanakan kegiatan pengabdian dengan mengundang perwakilan guru, orang tua dan siswa untuk Bersama-sama mendapatkan gambaran umum tentang pembelajaran menggunakan media ICT berupa Edmodo dan Schoology.

Pada kegiatan pengabdian yang pertama ini, dihadiri oleh guru, orang tua dan siswa. Kegiatan pengabdian ini dibuka secara resmi oleh kepala sekolah SMP IT Insan Mulia Manokwari dan dilanjutkan dengan ucapan terima kasih dari perwakilan guru SMP IT Insan Mulia Manokwari.

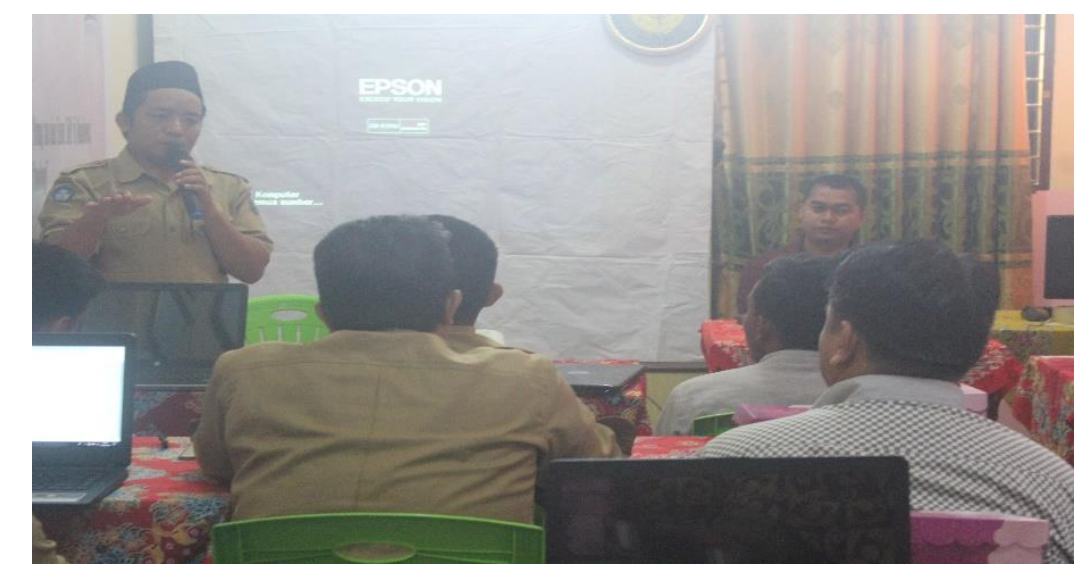

Gambar 1. Pembukaan kegiatan pengabdian oleh bapak kepala sekolah 
Jurnal Pengabdian Kepada Masyarakat

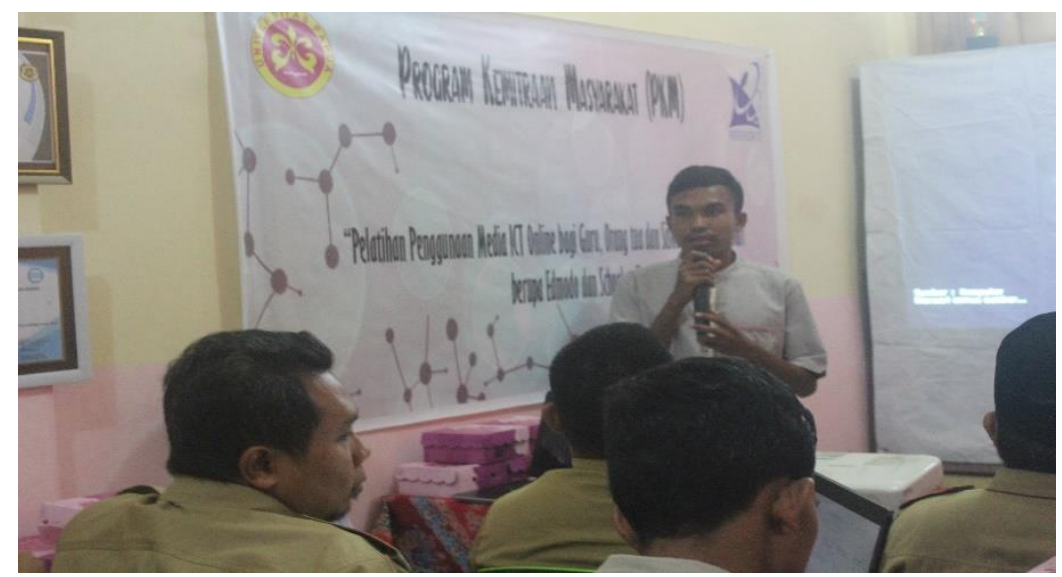

Gambar 2. Ucapan terima kasih dari perwakilan guru

Dalam pelatihan yang dilaksanakan ini dilaksanakan dalam suasana yang santai, sehingga peserta pelatihan dapat menerima materi yang disampaikan.

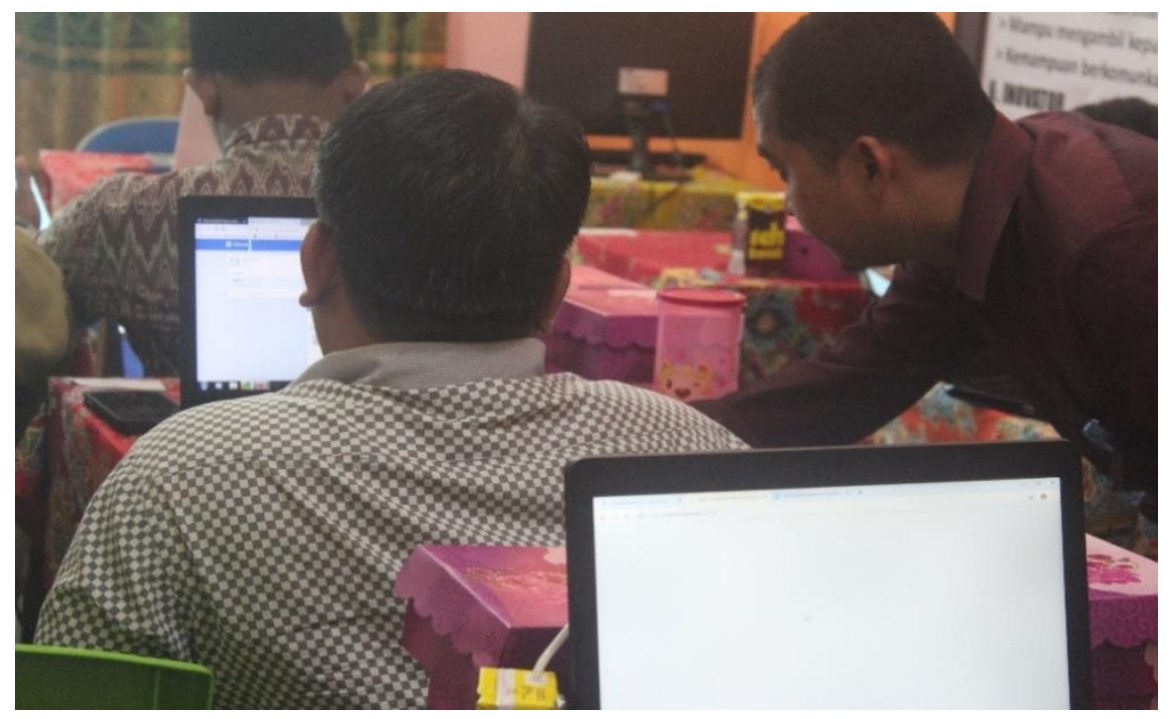

Gambar 3. Proses pembimbingan pelatihan oleh tim pengabdian

Untuk mengetahui respon positif dari kegiatan pelaksanaan pengabdian ini, maka diberikan angket setelah pelaksanaan pengabdian dilakukan. Angket respon ini terdiri atas 5 bagian utama yaitu tentang isi materi, penyampaian/pemaparan materi, diskusi/tanya jawab, praktik/pelatihan individu dan hasil pelatihan.

1. Isi Materi

Pada bagian ini, terdapat 4 pertanyaan yang diberikan kepada responden peserta pelatihan, dan hasil kuesionernya terlihat pada grafik berikut: 
Jurnal Pengabdian Kepada Masyarakat

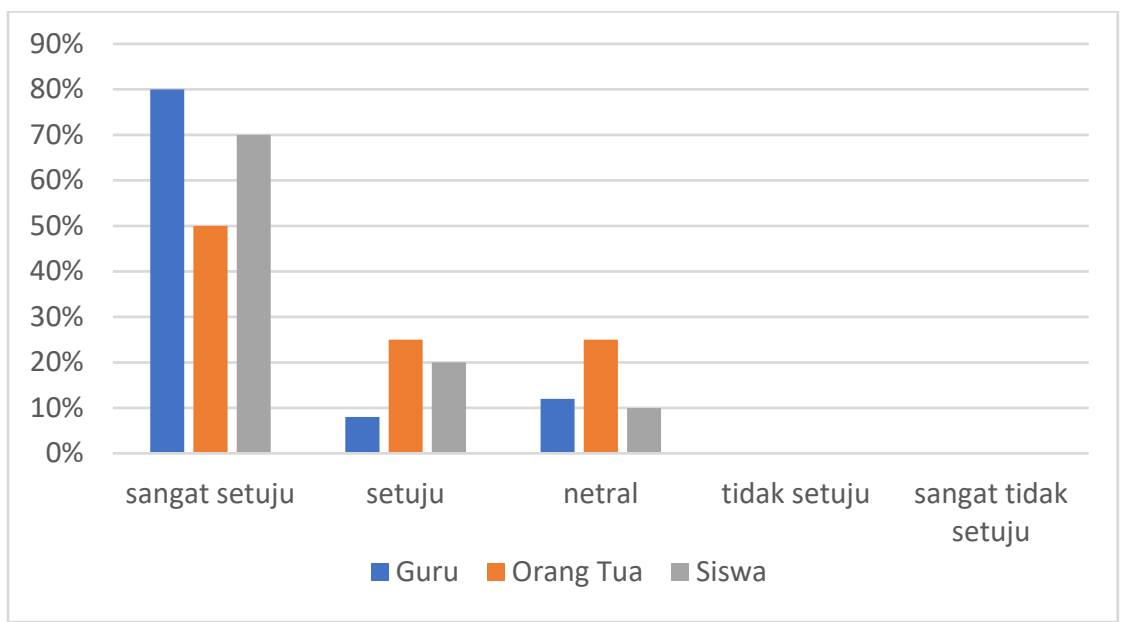

Gambar 4. Grafik berdasarkan isi materi

Dari grafik diatas terlihat bahwa baik guru, orang tua dan siswa lebih banyak yang sangat setuju dengan isi materi yang diberikan selama kegiatan pengabdian pelatihan dilaksanakan. Ini menandakan bahwa isi materi menarik buat guru, orang tua dan siswa.

\section{Penyampaian/Pemaparan Materi}

Pada bagian ini, terdapat 3 pertanyaan yang diberikan kepada responden peserta pelatihan, dan hasil kuesionernya terlihat pada grafik berikut:

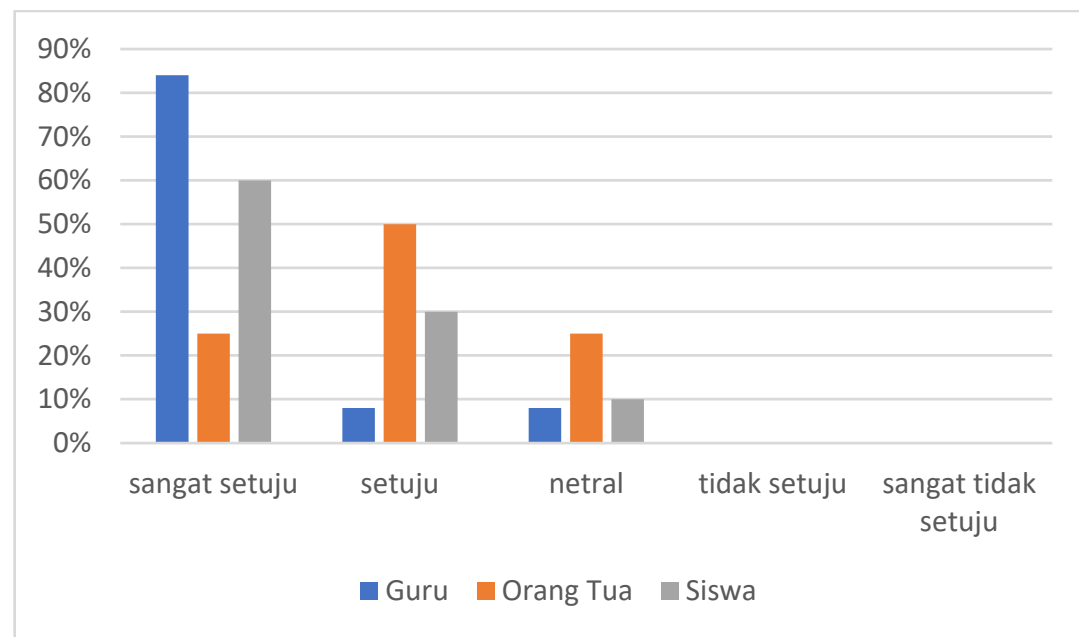

Gambar 5. Grafik berdasarkan Penyampaian/ Pemaparan materi

Dari grafik diatas terlihat bahwa baik guru, orang tua dan siswa lebih banyak yang sangat setuju dan setuju dengan penyampaian materi selama kegiatan pengabdian pelatihan dilaksanakan. Ini menandakan bahwa proses penyampaiannya dapat dipahami oleh buat guru, orang tua dan siswa.

\section{Diskusi/Tanya Jawab}

Pada bagian ini, terdapat 3 pertanyaan yang diberikan kepada responden peserta pelatihan, dan hasil kuesionernya terlihat pada grafik berikut: 
Jurnal Pengabdian Kepada Masyarakat

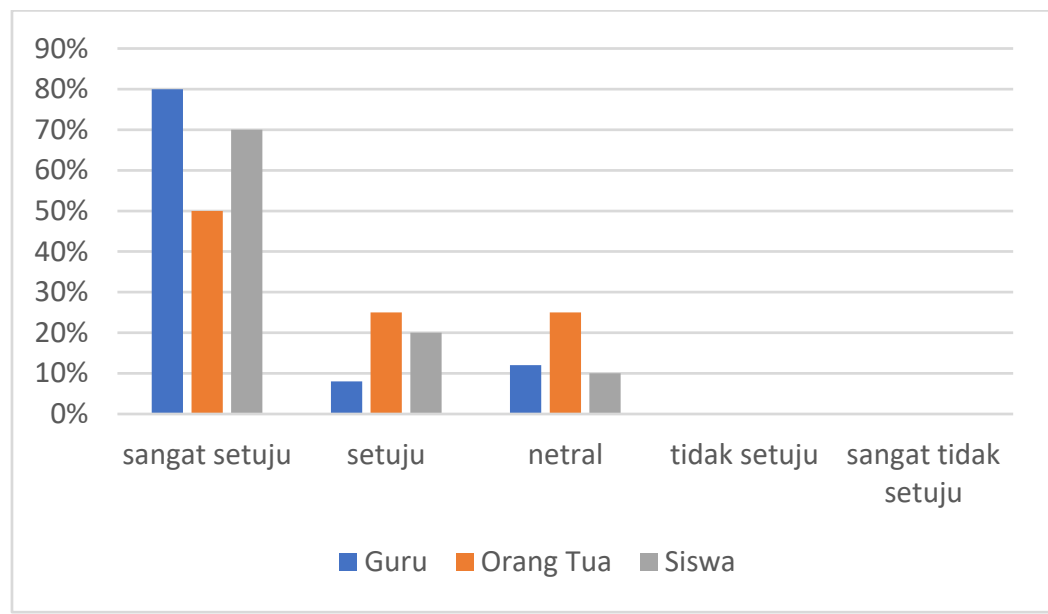

Gambar 6. Grafik berdasarkan Diskusi/ tanya jawab

Dari grafik diatas terlihat bahwa baik guru, orang tua dan siswa lebih banyak yang sangat setuju dan setuju serta netral dengan diskusi atau tanya jawab selama kegiatan pengabdian pelatihan dilaksanakan. Ini menandakan bahwa tim pengabdian memberikan kesempatan yang seluas-luasnya kepada peserta untuk bertanya atau berdiskusi dengan segala sesuatu yang belum dipahami.

\section{Praktik/Pelatihan Individu}

Pada bagian ini, terdapat 3 pertanyaan yang diberikan kepada responden peserta pelatihan, dan hasil kuesionernya terlihat pada grafik berikut:

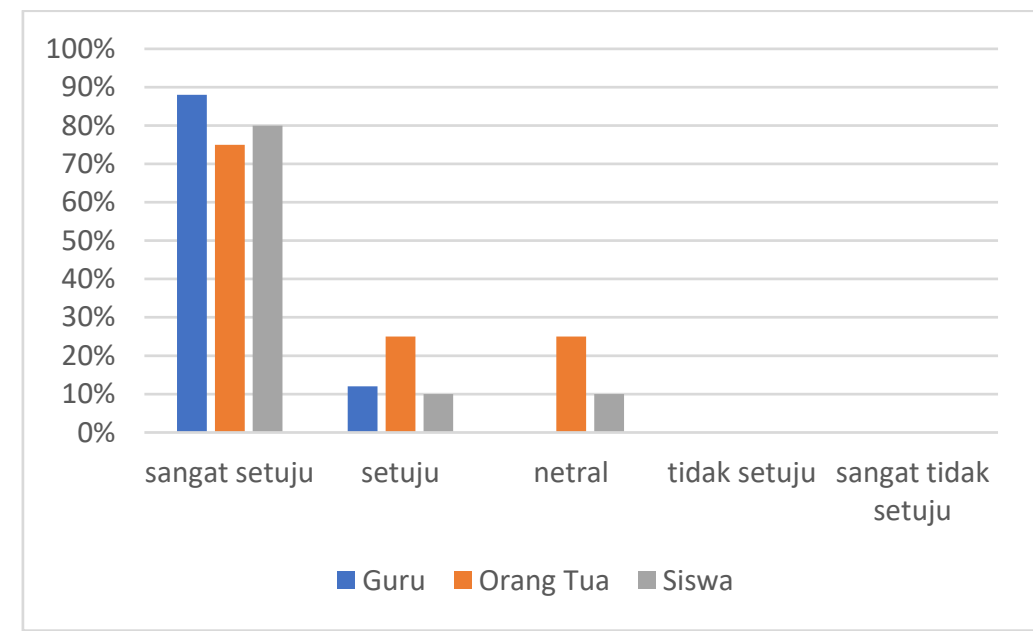

Gambar 7. Grafik berdasarkan Praktik/ pelatihan individu

Dari grafik diatas terlihat bahwa baik guru, orang tua dan siswa lebih banyak yang sangat setuju dan setuju serta netral dengan praktik/pelatihan individu selama kegiatan pengabdian pelatihan dilaksanakan. Ini menandakan bahwa tim pengabdian telah memfasilitasi dengan baik proses pelatihan baik kepada guru, orang tua maupun siswa.

\section{Hasil Pelatihan}

Pada bagian ini, terdapat 1 pertanyaan yang diberikan kepada responden peserta pelatihan, dan hasil kuesionernya terlihat pada grafik berikut: 
Jurnal Pengabdian Kepada Masyarakat

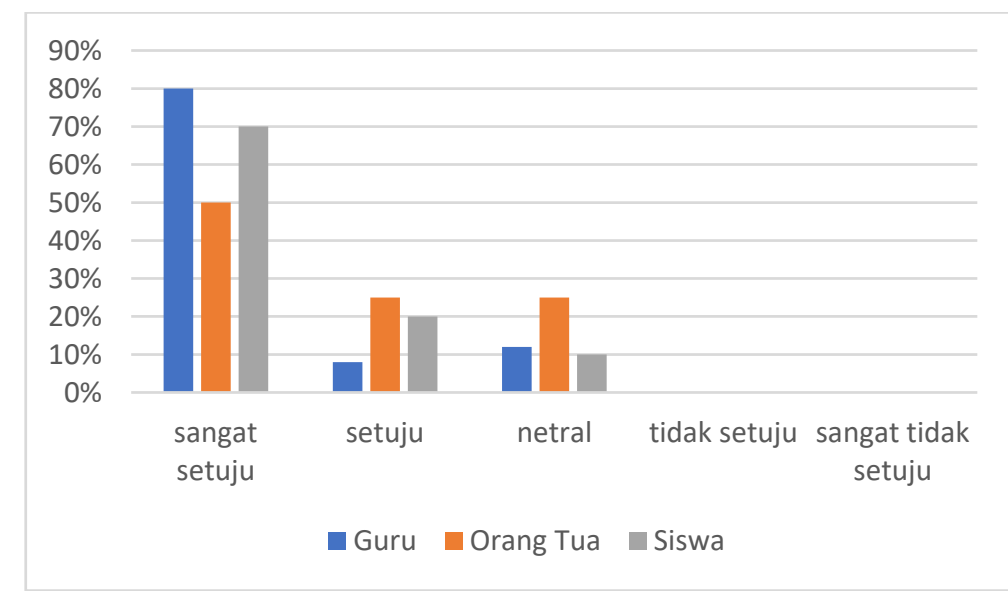

Gambar 8. Grafik berdasarkan Hasil pelatihan

Dari grafik diatas terlihat bahwa baik guru, orang tua dan siswa lebih banyak yang sangat setuju dan setuju serta netral dengan praktik/pelatihan individu selama kegiatan pengabdian pelatihan dilaksanakan. Ini menandakan bahwa sebagian guru, orang tua maupun siswa telah menggunakan Edmodo atau schoology dalam pembelajarannya.

\section{Simpulan dan Rekomendasi}

Dari hasil evaluasi dan temuan-temuan yang diperoleh dilapangan selama proses pelatihan yang dilaksanakan di sekolah mitra SMP IT Insan Mulia Manokwari, dapat disimpulkan bahwa program pengabdian masyarakat ini telah mampu memberikan manfaat yang positif baik kepada guru, orang tua maupun siswa pada bidang pembelajaran dengan menggunakaan media ICT berupa Edmodo dan Schoology. Proses pelatihan ini telah menambah pengetahuan dan keterampilan yang ada pada guru, siswa dan orang tua. Bentuk pelatihan seperti ini merupakan bentuk yang sangat efektif yang dapat memberikan penyegaran dan memberikan wawasan baru dalam prosese pembelajaran, sehingga kedepannya diharapkan dapat diterapkan di sekolah-sekolah lain terutama di Manokwari Papua Barat

\section{Acknowledgements}

Terima kasih kepada Kementerian Riset, Teknologi dan Pendidikan Tinggi atas dana Hibah Pengabdian Program Kemitraan Masyarakat (PKM) tahun pelaksanaan 2019.

\section{Daftar Pustaka}

Apriyani, Y., Sutisna, H., \& Adiwisasta, M. F. (2018). Cerdas Bermedia Sosial di Era Digital di Pondok Pesantren Daarul Muta'alimin Tasikmalaya. Jurnal Abdimas BSI, 155-162. 
Jurnal Pengabdian Kepada Masyarakat

Hikmawan, T., \& Sarino, A. (2018). Pemanfaatan Media Pembelajaran Berbasis Edmodo terhadap Motivasi Belajar Siswa Sekolah Menengah Kejuruan. Jurnal Pendidikan Manajemen Perkantoran, 226-233.

Kamil. (2004). Pembuatan Software Multimedia Interaktif Pembelajaran KimiaPada Pokok Bahasan Larutan Elektrolit. Bandung: Jurusan Kimia FPMIPA UPI.

Kuntarto. (2018). Materi Pelatihan Pengembangan e Learning. Tanjungpinang: Universitas Maritim Raja Ali Haji.

McLuhan, M. (2002). Understanding Media the Extension of Man. New York: St Louis University.

Nursidik, Y. (2007). Urgensi Media Pembelajaran dalam Kegiatan Belajar Mengajar. Semarang: UPT MKK.

Ulva, N. L., Kantun, S., \& Widodo, J. (2017). Penerapan e Learning Dengan Media Schoology untuk Meningkatkan Motivasi dan Hasil Belajar Siswa pada Kompetensi Dasar Mendiskripsikan Konsep Badan Usaha dalam Perekonomian Indonesia. Jurnal Pendidikan Ekonomi, 96-102. 